\title{
College Library Activities
}

\section{Thomas G. Kirk Chair \\ College Library Section}

The Association of College and Research $\mathrm{Li}$ braries is the professional home for college librarians. As so much is going on both within the College Library Section and the Association generally which will be of interest to college librarians, let me report briefly on some of these activities:

College Library Standards. At ALA Midwinter the ACRL Ad Hoc Committee to review certain portions of the 1975 standards organized and began its work. Chaired by Jackie Morris (Associate Director, University of the Pacific, Stockton, CA 95211), the Committee will give special attention to the quantitative aspects of the 1975 Standards.

Library Statistics. While not an exclusively college library-focused activity, the work of the ACRL Task Force on Library Statistics could be an important activity for college librarians. With the dearth of current academic library statistics, college librarians will welcome some organized effort to collect and disseminate statistics on college library operations. The Task Force is chaired by George Bailey (Claremont College Libraries, Claremont, CA 91711).

Non-Print Media Survey. In January the College Library Section's Ad Hoc Committee on Non-Print Media and the College Library distributed a questionnaire to five hundred colleges. This survey is intended to provide a basis for describing the present relationship between non-print media and libraries in small academic institutions. Based on the conditions identified by the questionnaire results the Committee will explore what actions the Section and the Association might take in the development of standards, addressing the special needs and problems of college libraries, and recommend programs and activities on non-print media. The chair of the Committee, B. Anne Commerton (Director of Libraries, SUNY, Oswego, NY 13120), expects the results of the questionnaire to be available in time for discussion by the Committee at the Los Angeles Conference.

Libraries in Closing Colleges. As a result of a recommendation from the Impact of National Policy and National Library Developments on the College Library Committee the College Section will appoint an Ad Hoc Committee on Libraries in Closing Colleges. The Committee will be charged to: "identify the severity of the college closing problem in the next decade and if a significant problem is identified then the Committee would continue to explore and suggest ways that the College Library Section could assist libraries in this problem including the formulation of a checklist to assist in closing a library." The chair and membership of the com- mittee will be appointed in time for an organizational meeting at ALA this summer.

CLIP Notes. The CLIP (College Library Information Packet) Notes Committee reported to the Executive Committee that their work on a package of material on online bibliographic search services in college libraries is continuing. A questionnaire has been developed and was circulated in December. Once the material has been assembled the CLIP Notes package, which is modeled after the Association of Research Libraries SPEC Kits, will be sold through the ACRL office. Presently CLIP Notes packages on Performance Appraisal, Collection Development and Job Descriptions are available. These are available from ACRL headquarters in Chicago (consult C\&RL News, February 1982, for prices and information on how to order).

The Committee is ready to work on additional subjects and would like to hear from college librarians about subjects for which they would like sample documents, and comparative data on how college libraries deal with common services, issues or problems. The chair of the Committee is P. Grady Morein, Library Director, University of Evansville, Evansville, IN 47702.

Executive Committee. The Executive Committee of the College Section discussed a number of items of business at its Midwinter meetings in addition to the committee activities itemized above. The most noteworthy were l) the concept of a price index for books useful to college librarians, and 2) interest in a mechanism for greater membership interaction about the problems of college libraries during ALA conferences. The idea of developing a price index for books which is useful to college librarians was brought to our attention by the work of the Library Materials Price Index Committee of the Resources Section of Resources and Technical Services Division. A recommendation to use books reviewed by Choice magazine as the basis for the index has been proposed by a member of that Committee. Members of the Section who have a concern about such a price index and how it might be calculated are urged to write to Richard Werking, Director of Libraries, Trinity University, San Antonio, TX 78284.

The Executive Committee will explore ways the Section can facilitate discussion among the Section's membership during ALA conferences. One suggestion is to devote a portion of the Section's program time to small group discussions on topics of current concern.

ALA Annual Conference. Looking forward to Los Angeles, the College Section in addition to the regular meetings of the Section's committees will have two meetings especially for the membership. The first will be an open meeting/hearing by the Continuing Education Committee. This hearing 
will explore ways in which the CE Committee can help librarians new to the college library field get involved in the professional activities and associations, particularly ACRL and CLS. Those who are concerned about this problem are urged to attend that committee meeting on Sunday, June 26, at 4:30 p.m.

The Section's business meeting and program will be Sunday, June 26, from 9:30-11:00 a.m. The program, "Periodical Selection in College Libraries: Reports of Practitioners," will feature three refereed papers which will focus on specific programs undertaken to deal with periodicals in collections which serve undergraduates.

The Executive Committee is mindful of the im- portance of membership involvement in the work of the Section. Despite the limits imposed by time and travel funds many college librarians have devoted much time to the College Section. On behalf of the Executive Committee I want to express our gratitude for membership contributions. I want to urge other college librarians to get involved in the work of the Association and the Section. If you have a concern about an issue in college librarianship please communicate it to me. We, the officers of the Section, look forward to a busy and exciting conference in Los Angeles. We hope you'll be part of it.-Thomas Kirk, College Librarian, Berea College, Berea, KY 40404.

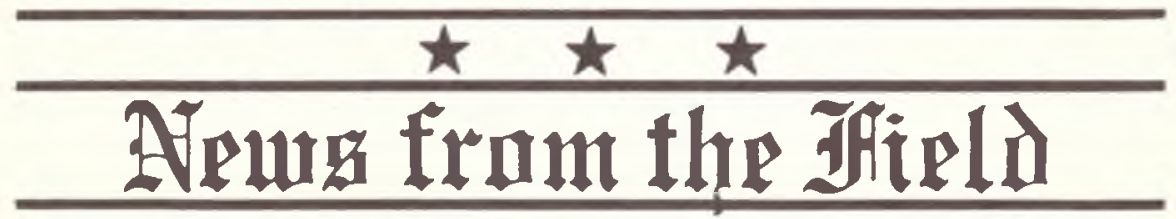

\section{ACQUISITIONS}

- Cornell University Libraries have received the papers of Harry W. Frantz, a journalist for the United Press from 1920 to 1965 . The collection covers such diverse subjects as diplomatic history, Latin America, aviation, political history, World Wars I and II, photography, and journalism.

- Frostbur state College, Maryland, has received an extensive collection of books on military and diplomatic history from the estate of the late John W. Davis, Jr., a member of the college's history faculty for 13 years prior to his death in 1981 . The more than 3,100 volumes cover the two world wars and recent European military history.

- The Maryland Historical Society Library, Baltimore, has received the personal and professional archive of Eubie Blake (1883-1983), Baltimore-born pianist, composer and songwriter. Songs and instrumental pieces in manuscript, including Charleston Rag (1899), form the heart of the collection together with extensive documentation of Blake's collaboration with singer and lyricist Noble Sissle (1889-1975), Flournoy Miller, Milton Reddie, and others. The musical comedy Shuffle Along, presented on Broadway in 1921, is represented in correspondence, box office records, programs, scores and parts, photographs, and printed sheet music. Blake's involvement in other productions is similarly documented. Photographs, news clippings, and printed ephemera support the collection's primary materials.

-Simpson College, Indianola, Iowa, has opened the Avery O. Craven Collection. Craven (1885-1980) was a well-known American historian who specialized in mid-19th century American history, particularly the Antebellum South. The collection includes his personal library of over 2,000 volumes, notes, manuscripts, correspondence with historians Charles Beard, Frederick Jackson Turner, and others, and memorabilia. Formal dedication of the collection will take place on October 6 .

-The University of Houston's M.D. Anderson Library has received a collection of the papers and correspondence of Stephen F. Austin (1793-1836). The Austin Collection, presented to the library by a Houston businessman in honor of Texas Independence Day, includes the first census taken in Texas; some of the earliest documents relating to Austin's first Texas colony; speeches and letters written during Austin's tour of the United States to secure loans for the Republic of Texas; and a miniature broadside announcing Austin's death at the home of Judge McKinstry.

- The University of North Carolina at CHAPEL Hill's Southern Historical Collection has received the papers of noted alumnus Allard K. Lowenstein. This comprehensive collection covers Lowenstein's life from youth to his death in 1980 and includes personal material, records of his political and civil rights activities in the 1960s and 1970 s, his congressional service, his humanitarian efforts, and his United Nations appointment. The library staff expects to open the papers for research by July 1985 . 